\title{
A NOVEL BIOMARKER RENALASE AND ITS RELATIONSHIP WITH ITS SUBSTRATES IN SCHIZOPHRENIA
}

\section{NOVI BIOMARKER RENALAZA I NJEN ODNOS SA SVOJIM SUPSTRATIMA U SHIZOFRENIJI}

\author{
Zekiye Catak ${ }^{1}$, Esra Kocdemir ${ }^{2}$, Kader Ugur 3 , Meltem Yardim ${ }^{4}$, İbrahim Sahin ${ }^{4,5}$, \\ Hilal Kaya ${ }^{6}$, Suleyman Aydin ${ }^{4}$ \\ ${ }^{1}$ Department of Clinical Biochemistry, Health Sciences University, Elazig Training and Research Hospital, \\ 23100, Elazig, Turkey \\ ${ }^{2}$ Department of Clinical Biochemistry, Kovancilar State Hospital, 23100, Elazig, Turkey \\ ${ }^{3}$ Department of Internal Medicine (Endocrinology and Metabolism Diseases), Medical School, Firat University, \\ 23119, Elazig, Turkey \\ ${ }^{4}$ Department of Medical Biochemistry and Clinical Biochemistry, (Firat Hormones Research Group), Medical \\ School, Firat University, 23119, Elazig. Turkey \\ ${ }^{5}$ Department of Medical Biology, Medical School, Erzincan Binali Yildirim University, 24100, Erzincan, Turkey \\ ${ }^{6}$ Department of Psychiatry, Elazig Mental Health Hospital, 23100, Elazig, Turkey
}

\section{Summary}

Background: Schizophrenia, particularly the form related to excessive dopamine (DA), is a chronic psychotic disorder affecting millions of people worldwide. Renalase metabolizes its catecholamine (CA) substrates, including DA, suggesting that there might be an association between renalase levels and schizophrenia occurrence. Therefore, the current study aimed to evaluate the renalase and CA levels in the serum of patients with schizophrenia.

Methods: The study was conducted with thirty-three schizophrenia patients and an age- and gender-matched group of thirty-one controls. Renalase and CA levels were measured by using an enzyme-linked immunosorbent assay (ELISA).

Results: Renalase levels were significantly lower in the schizophrenia patients than in the control group $(p<0.05)$, whereas DA levels were significantly higher $(p<0.05)$. The epinephrine (Epi) levels of both groups were similar $(p=0.186)$, while the norepinephrine levels in patients with schizophrenia were significantly lower than those in the control group $(p<0.05)$. The areas under the curves for

Address for correspondence:

Prof. Dr. Suleyman Aydin

Department of Medical Biochemistry and Clinical Biochemistry, (Firat Hormones Research Group), Medical School,

Firat University, 23119, Elazig, Turkey

e-mail: saydin1@hotmail.com, saydin1@firat.edu.tr

\begin{abstract}
Kratak sadržaj
Uvod: Shizofrenija, posebno oblik sa povećanim dopaminom (DA) je hronični psihijatrijski poremećaj od koga boluju milioni ljudi širom sveta. Relanaza metaboliše supstrate kateholamine (CA), uključujući DA, što ukazuje da može da postoji veza između nivoa relanaze i pojave shizofrenije. Shodno ovome, ovo izučavanje je imalo za cilj da proceni nivoe relanaze i CA u serumu pacijenata sa shizofrenijom. Metode: Izučavanje je obuhvatilo trideset tri pacijenta sa shizofrenijom i trideset jednu osobu iste starosti i pola kao kontrolnu grupu. Nivoi renalaze i CA mereni su primenom ELISA metode.

Rezultati: Nivoi renalaze bili su značajno niži kod pacijenaza sa shizofrenijom nego u kontrolnoj grupi $(p<0,05)$, dok su nivoi DA bili značajno viši $(p<0,05)$. Nivoi epinefrina (Epi) u obe grupe bili su manji $(p=0,186)$, dok su nivoi norepinfrina u pacijenata sa shizofrenijom bili značajno niži nego u kontrolnoj grupi $(p<0,05)$. Površina ispod krive za renelaze-dopamin i renelaze-epinefrin odnose bili su 0,805, $95 \%$ konfidens interval Cl: 0,594-0,859 ( $p=0,032)$; i 0,656, 95\% Cl: 0,520-0,791 ( $p=002)$.
\end{abstract}

List of abbreviations: BMI, Body Mass Index; CA, catecholamines; CNS, central nervous system; DA, dopamine; ELISA, enzyme-linked immunosorbent assay; Epi, epinephrine; FAD, flavin adenine dinucleotide; FG, fasting glucose; HDL-C, high-density lipoprotein cholesterol; LDL-C, low-density lipoprotein cholesterol; MAO, monoamine oxidase; NE, norepinephrine; ROC, Receiver Operating Characteristics; SCID, Structured Clinical Interview for DSM-IV; SSAO, semicarbazidesensitive amine oxidase; TC, total cholesterol; TG, triglyceride. 
the renalase-dopamine, renalase-norepinephrine and renalase-epinephrine ratios were $0.805,95 \%$ confidence interval $(\mathrm{Cl})$ : 0.699-0.912 ( $\mathrm{p}<0.001) ; 0.726,95 \% \mathrm{Cl}$ : $0.594-0.859(p=0.032)$; and $0.656,95 \% \mathrm{Cl}: 0.520$ $0.791(p=0.02)$.

Conclusions: The high DA levels in patients with schizophrenia might be due to low renalase levels. Renalase enzyme levels may play a substantial role in the pathophysiology of schizophrenia. Thus, this enzyme might be a new future target for the treatment and diagnosis of schizophrenia after intrabrain renalase and DA dynamics have been further evaluated.

Keywords: catecholamine, dopamine, renalase, schizophrenia

\section{Introduction}

Schizophrenia is a complex psychotic disorder, and its pathophysiology is not yet clear (1). Until now, the dopamine (DA) theory, one of the biochemical theories of schizophrenia pathophysiology, has received the most attention $(2,3)$. This theory suggests an overactive state in dopaminergic stimulation in certain brain regions of patients $(2,4)$. The dopamine theory of schizophrenia is the principal basis of antipsychotic drug treatment (5-7). On the other hand, it has been argued that genes involved in the dopaminergic system have effects on neurocognitive dysfunction in schizophrenia (8). These findings indicate a relationship between the pathophysiology of schizophrenia and DA. DA is an inhibitory neurotransmitter in the nervous system, and it has an important role in working memory, emotion and attention $(9,10)$. Additionally, DA is secreted by tubule cells in the kidneys and has an important role in blood pressure homeostasis with other catecholamines [epinephrine (Epi) and norepinephrine (NE)] (11). Renalase, a novel protein discovered by Xu et al. (12), was proposed to play a role in regulating catecholamines. The functions of renalase were first described in the human kidney, heart and plasma (13). Then, Hennebry et al. (14) showed that renalase and different splice variants of the renalase gene were present in brain tissue and argued that renalase may play a potent role in regulating concentrations of monoamine neurotransmitters in the brain. Important studies aimed at understanding its function showed that renalase is a flavin adenine dinucleotide (FAD)-dependent protein and the synthesis, secretion, and activity of renalase are mainly regulated by renal function, renal perfusion and catecholamine levels (DA, NE, and Epi) in the plasma (13). Furthermore, it was shown that renalase oxidizes DA, NE, and Epi in the presence of FAD (12). In the central nervous system (CNS), monoamines are degraded by monoamine oxidase (MAO-A and MAO-B isoforms) and semicarbazide-sensitive amine oxidase (SSAO) enzymes (15-17). Another study demonstrated significant changes in brain MAO-A and MAO-B efficacy caused by renalase deficiency in knock-out mice (18).
Zaključak: Visoki nivoi DA u pacijenata sa shizofrenijom mogu biti usled niskih nivoa renalaze. Nivoi renalaze enzima mogu imati značajnu ulogu u patofiziologiji shizofrenije. To znači da ovaj enzima može imati značajnu ulogu u tretmanu i dijagnostikovanju shizofrenije te ona treba dalje da bude izučavana kao i dinamika DA.

Ključne reči: kateholamini, dopamin, renalaze, shizofrenija

Proper distribution, concentration and homeostasis of neurotransmitters in the central and peripheral nervous system have a critical role in healthy brain activities.

It has also been recently hypothesized that schizophrenia is associated with the synthesis and release of the renalase enzyme synthesized in many tissues, including the brain in particular (19). According to this hypothesis, when renalase is synthesized below the physiological dose, catecholamines, including DA, are degraded to a lesser extent, and thus, schizophrenia might develop. Therefore, the aim of this study was to examine the renalase and catecholamine levels (DA, NE, and Epi) in patients with schizophrenia to assess associations between renalase/catecholamine levels and schizophrenia.

\section{Materials and Methods}

Thirty-three patients with schizophrenia who visited a mental health hospital in Elazig City, Turkey, were included in the present study. The participants are similar in age (control: $43 \pm 9$ years; schizophrenia: $42 \pm 11$ years) and have similar body mass indices (control: $26.70 \pm 3.30 \mathrm{~kg} / \mathrm{m}^{2}$; schizophrenia: $26.15 \pm 4.39 \mathrm{~kg} / \mathrm{m}^{2}$ ). The patients were selected according to the following inclusion criteria: 1patients were diagnosed with schizophrenia based on the Structured Clinical Interview for DSM-IV (SCID), 2- patients were between 18 and 60 years old, 3patients were ill for at least 4 years, 4-patients did not use substances, 5-patients only used antipsychotic medication, and 6-patients had no chronic illnesses such as diabetes mellitus. The antipsychotic drugs that the patients had been receiving were clozapine (8), risperidone (16), haloperidol (7), sulpiride (7), quetiapine (16), olanzapine (10), lorazepam (5), and biperiden (8).

Thirty-one healthy controls who had not consumed alcohol or psychoactive drugs and had not taken any medicine affecting neuroamines and renalase metabolism were included. The control group was comprised shortly after the patient group 
in order to pair for sex and age. Based on unstructured interviews, the control group had no current or personal/family history of any psychiatric illness. The blood pressures of all participants were measured using the standard sitting position. This study was approved by the local investigation and ethics committee (Firat University Ethics Committee; Date; 21. 11 2017; Number; 231591). Informed consent forms were signed by all participants' relatives after a psychiatrist explained the research protocol and procedures to them.

\section{Biochemical analyses}

Fasting blood samples drawn from the antecubital veins of all participants were collected and centrifuged at $4000 \times \mathrm{rpm}$ for $5 \mathrm{~min}$. Subsequently, the samples were immediately analyzed for serum levels of fasting glucose (FG), high-density lipoprotein cholesterol (HDL-C), low-density lipoprotein cholesterol (LDL-C), total cholesterol (TC), and triglycerides (TG) by routine laboratory procedures in a Cobas 6000 analyzer (Roche Hitachi, Tokyo, Japan) at the biochemistry laboratory of the mental health hospital. Then, sera were separated, transferred into Eppendorf tubes and stored at $-20{ }^{\circ} \mathrm{C}$ until renalase, $\mathrm{DA}, \mathrm{NE}$ and Epi measurements were performed. Serum concentrations of renalase, DA, NE and Epi were analyzed by the ELISA technique (20). All measurements were blindly recorded by the same person. All of the samples and standards were analyzed twice. The detectable ranges of human renalase (Catalog no: 201-12-5371 Sunred Biological Technology Co., Ltd., Shanghai, CHINA), dopamine (Catalog no: EU0392 Fine Biotech Co., Ltd. Wuhan, CHINA), norepinephrine (Catalog no: EU2565 Fine Biotech Co., Ltd. Wuhan, CHINA) and epinephrine (Catalog no: EU2563 Fine Biotech Co., Ltd. Wuhan, CHINA) were 3-700 ng/mL, $1.56-100 \mathrm{ng} / \mathrm{mL}, 15.625-1000$ $\mathrm{pg} / \mathrm{mL}$ and $7.813-500 \mathrm{pg} / \mathrm{mL}$, respectively. In this study, dopamine, norepinephrine and renalase values are reported as $\mathrm{ng} / \mathrm{mL}$ values, while epinephrine is reported as $\mathrm{pg} / \mathrm{mL}$ values to easily compare previous results regarding those parameters mentioned above. Previous researchers reported those parameters as either $\mathrm{pg} / \mathrm{mL}$ or $\mathrm{ng} / \mathrm{mL}$ values. The interassay coefficients of renalase, DA, NE and Epi were $<12 \%$, $<10 \%,<10 \%$ and $<10 \%$, respectively. The intraassay variation coefficients of renalase, DA, NE and Epi were $<10 \%,<8 \%,<8 \%$ and $<8 \%$, respectively. Renalase, DA, NE and Epi levels were analyzed using a ChroMate Microplate Reader P4300 (Awareness Technology Instruments, Palm City, FL, USA).

\section{Statistical analysis}

All parameters were analyzed by using the social science statistical package (SPSS Inc., Chicago, IL,
USA) software version 22. The variables were investigated using visual (histograms/probability plots) and analytical (Kolmogorov-Smirnov/Shapiro-Wilk's tests) methods regardless of their distribution. When the variables were distributed normally, Student's t-tests were used to identify statistically significant differences between the two groups. When the variables were distributed nonnormally, Mann-Whitney $U$ tests were used to compare differences between two independent groups. The Chi-squared test was used for categorical variables. Data are presented as the mean \pm standard deviation or median (min-max). The ability of the serum renalase/dopamine, renalase/epinephrine and renalase/norepinephrine ratios in predicting the presence of schizophrenia were calculated with a Receiver Operating Characteristics (ROC) curve analysis. When a significant cut-off value was obtained by Youden's index, the sensitivity, specificity and positive and negative predictive values were shown. Differences between the groups were considered significant if the $p$ values were less than 0.05 .

\section{Results}

The demographic features [age, Body Mass Index (BMI)], systolic and diastolic blood pressure, fasting glucose (FG) and lipid parameters (HDL-C, LDL-C, TC and TG levels) of schizophrenic and control groups are presented with their $p$ values in Table I. Renalase was significantly lower in the schizophrenia patients than in the control group (181.65 \pm $20.86 \mathrm{ng} / \mathrm{mL} ; 543.74 \pm 54.35 \mathrm{ng} / \mathrm{mL}, p<0.05)$, while DA was significantly higher in the schizophrenia patients $(91.44 \pm 12.58 \mathrm{ng} / \mathrm{mL} ; 52.39 \pm 9.57$ $\mathrm{ng} / \mathrm{mL}, \mathrm{p}<0.05)$ (Figure 1). The epinephrine levels of both groups were similar $(55.89 \pm 9.8 \mathrm{pg} / \mathrm{mL}$; $52.71 \pm 9.18 \mathrm{pg} / \mathrm{mL}, p=0.186$ ), while the NE levels in the schizophrenia patients were significantly lower than those in the control group (58.56 \pm 5.82 $\mathrm{pg} / \mathrm{mL} ; 72.04 \pm 5.88 \mathrm{pg} / \mathrm{mL}, p<0.05$ ) (Figure 2).

The areas under the curves of the renalasedopamine, renalase-norepinephrine and renalaseepinephrine ratios were $0.805,95 \%$ confidence interval $(\mathrm{Cl}): 0.699-0.912(\mathrm{p}<0.001) ; 0.726,95 \% \mathrm{Cl}$ : $0.594-0.859(p=0.032)$; and $0.656,95 \% \mathrm{Cl}$ : $0.520-0.791(p=0.02)$, respectively (Figure 3$)$. Data on the specificity and sensitivity of certain cutoffs of renalase-dopamine, renalase-norepinephrine and renalase-epinephrine ratios are also shown in Table II. The ROC curve analysis of the renalase and DA ratio had a specificity of $90.9 \%$, a sensitivity of $64.5 \%$, a positive predictive value of $86.9 \%$ and a negative predictive value of 73.1 with a cutoff value of 2.7. 
Table I Demographic characteristics, blood pressures and biochemical parameters in patients with schizophrenia and in healthy controls.

\begin{tabular}{|c|c|c|c|}
\hline Parameters & Schizophrenia (n:31) & Control (n:33) & $\mathrm{p}$ value \\
\hline Age (Mean \pm Standard deviation) & $42 \pm 11$ & $43 \pm 9$ & 0.694 \\
\hline Gender (Male/Female) & $23 / 8$ & $23 / 10$ & 0.689 \\
\hline BMI $\left(\mathrm{kg} / \mathrm{m}^{2}\right)$ (Mean \pm Standard deviation) & $26.15 \pm 4.39$ & $26.70 \pm 3.30$ & 0.199 \\
\hline $\begin{array}{l}\text { Systolic blood pressure } \\
\text { (mmHg; Mean } \pm \text { Standard deviation) }\end{array}$ & $115.8 \pm 6.7$ & $112.4 \pm 7.9$ & 0.096 \\
\hline $\begin{array}{l}\text { Diastolic blood pressure } \\
\text { (mmHg; Mean } \pm \text { Standard deviation) }\end{array}$ & $72.9 \pm 7.3$ & $73.0 \pm 8.0$ & 0.971 \\
\hline FG (mmol/L) (Median, min-max) & $5.72(4.41-8.881)$ & $5.40(4.91-8.2)$ & 0.016 \\
\hline HDL-C (mmol/L) (Median, min-max) & $1.341(0.59-1.96)$ & $1.293(0.57-3.64)$ & 0.013 \\
\hline LDL-C (mmol/L) (Median, min-max) & $2.14(0.58-5.14)$ & $2.69(0.51-4.58)$ & 0.003 \\
\hline TC (mmol/L) (Median, min-max) & $1.16(3.96-2.087)$ & $2.087(2.47-4.57)$ & 0.005 \\
\hline TG (mmol/L) (Median, min-max) & $1.98(0.51-4.47)$ & $1.161(0.58-4.47)$ & 0.009 \\
\hline Uric acid (mmol/L) & $0.274(0.03-0.037)$ & $0.267(0.029-0.031)$ & 0.022 \\
\hline Creatinine $(\mathrm{mmol} / \mathrm{L})$ & $0.080(0.009-0.001)$ & $0.0619(0.001-0.002)$ & 0.000 \\
\hline
\end{tabular}

BMI, body mass index; FG, fasting glucose; HDL-C, high-density lipoprotein cholesterol; LDL-C, low-density lipoprotein cholesterol; TC, total cholesterol; TG, triglyceride.

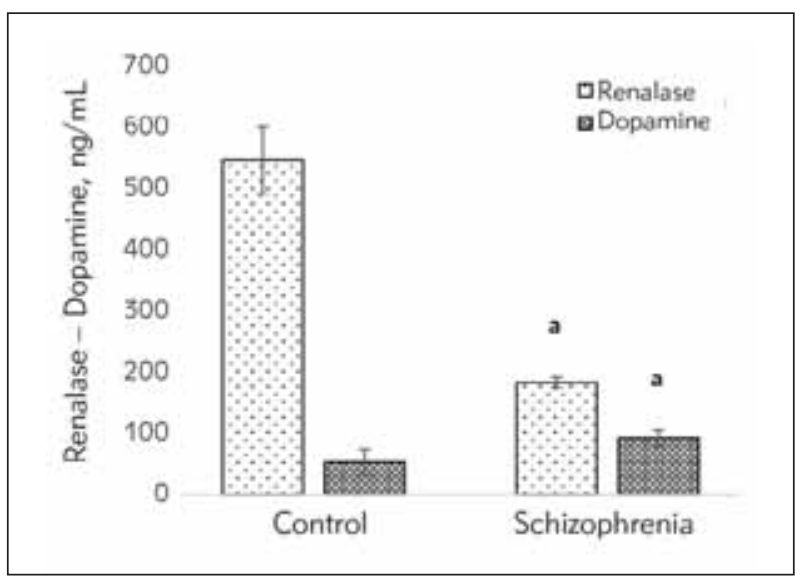

Figure 1 Comparison of renalase and dopamine levels in patients with and without schizophrenia

a: $p<0.05$.

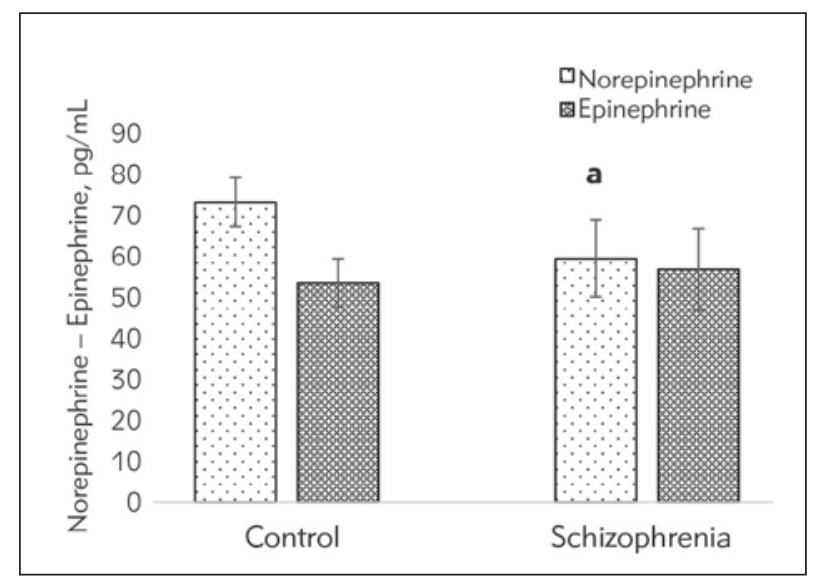

Figure 2 Comparison of epinephrine and norepinephrine levels in patients with and without schizophrenia a: $p<0.05$. 
Table II Recommended limit values for the renalase-dopamine, renalase-norepinephrine and renalase-epinephrine ratios.

\begin{tabular}{|l|c|c|c|c|c|}
\hline \multicolumn{2}{|c|}{ Parameters } & $\begin{array}{c}\text { Sensitivity } \\
(\%)\end{array}$ & $\begin{array}{c}\text { Specificity } \\
(\%)\end{array}$ & $\begin{array}{c}\text { Positive predictive } \\
\text { value (\%) }\end{array}$ & $\begin{array}{c}\text { Negative predictive } \\
\text { value (\%) }\end{array}$ \\
\hline Cut-off of renalase-dopamine ratio & 2.700 & 64.5 & 90.9 & 86.9 & 73.1 \\
\hline $\begin{array}{l}\text { Cut-off of renalase-norepinephrine } \\
\text { ratio }\end{array}$ & 4666 & 76.6 & 78.8 & 76.6 & 76.4 \\
\hline Cut-off of renalase-epinephrine ratio & 5885 & 61.2 & 66.6 & 63.3 & 64.7 \\
\hline
\end{tabular}

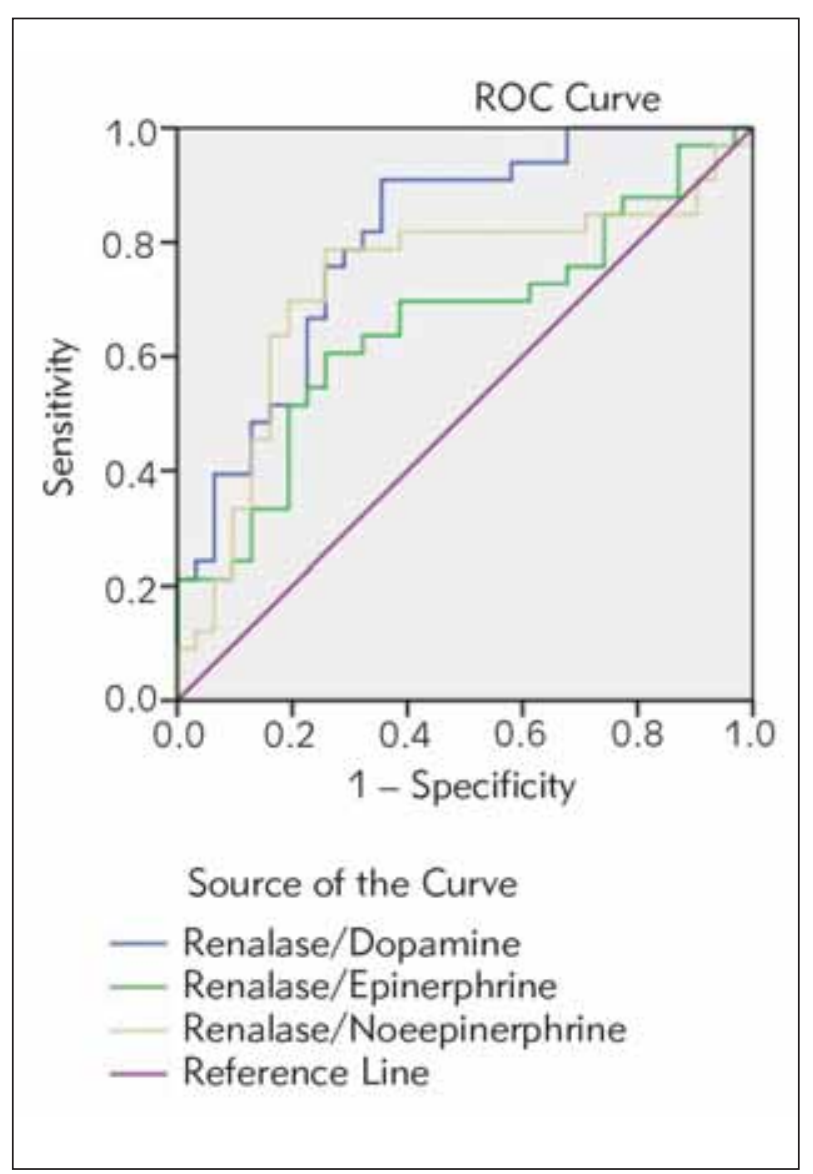

Figure 3 ROC curves obtained for the renalase-dopamine, renalase-norepinephrine and renalaseepinephrine ratios.

\section{Discussion}

There is a link between schizophrenia and excessive levels of DA, a molecule that belongs to the catecholamine (CA) family (21-23). CAs have their own signaling pathways throughout the body, bind to adrenergic (Epi, NE) and dopaminergic receptors and affect certain cell-types largely depending on the tissue-specific distribution of receptors $(24,25)$. It was recently reported that renalase is mainly secreted into the blood by the kidneys and that it degrades CAs (26, 27 ). It has been most recently hypothesized that there might be an association between DA and renalase levels and, thus, schizophrenia (19). Further, the possibility that changes in renalase levels cause a central overload of DA inspired us to focus on renalase in schizophrenia (28). Therefore, this work is the first study to explore serum renalase, DA, Epi and NE in patients with schizophrenia to characterize the relationship between catecholamines and renalase levels.

In this work, for the first time, we have shown that there are strikingly lower renalase (approximately 4-fold lower) serum concentrations in patients with schizophrenia than in a control group, while dopamine levels are higher in patients with schizophrenia than in a control group. The increase in DA serum levels was probably due to the decreased serum renalase because the renalase enzyme (an adenine dinucleotide-FAD-dependent monoamine oxidase) metabolizes dopamine, epinephrine, and norepinephrine catecholamines. If so, when circulating concentrations of renalase are below the physiological threshold necessary for metabolizing catecholamines, especially dopamine, schizophrenia may arise.

This result also indicates that low renalase and its effects on other neuroamine pathways in the CNS may be an underlying mechanism of schizophrenia pathophysiology. We assumed that insufficient renalase fails to metabolize DA at the normal physiological level, and this might cause high levels of DA that are linked with schizophrenia. Supporting this idea, it has been previously reported that renalase deficiency caused an increase in plasma concentrations of Epi, NE, and DA (18, 29). The NE level in the schizophrenia patients was lower than that in the control group in the present study.

We also reported here that there was a trend towards elevated Epi levels in patients with schizophrenia compared to the control group. Santos et al. (18) reported that renalase deficiency in $\mathrm{KO}$ mice was accompanied by critical alterations in the central and intestinal effects of catecholamine-degrading enzymes, such as MAO-A and -B and catechol-O-methyltransferase. They suggested that upon renalase insufficiency, both the central and peripheral monoaminergic pathways may expose tissue-specific regional effects of the enzymes that ultimately control regional catecholamine levels. 
In this work, it is unclear why NE decreases in schizophrenia subjects instead of increasing in the presence of reduced renalase. This finding indicates that the relationship between renalase and CA may be more complex, but there is a clear relationship among renalase, DA and schizophrenia. There is a known link among Epi, NE and blood pressure (29, 30). In this study, we found that the blood pressure values of schizophrenia and control groups were similar to each other. We thought that the decrease in NE might control blood pressure, although it was reported that increases in plasma concentrations of Epi, NE, and DA are a scientific sign for increased sympathetic nervous system activity when renalase is deficient. Our study does not confirm the previous findings concerning blood pressure $(18,31,32)$.

We first detected that renalase-dopamine and renalase-norepinephrine ratios have a discriminative ability in the diagnosis of schizophrenia disease as detected through the receiving operating curve analysis. Thus, these ratios may be quite useful for the diagnosis of schizophrenia in the future. However, blood renalase and dopamine might be two of the most useful measures for schizophrenia disease. Diseases that primarily affect renalase, such as kidney hyperplasia or hypertrophy, will cause disproportionate increases in dopamine levels compared with physiological levels. The ratio of renalase to dopamine is beneficial in sorting out schizophrenia disease, in which the ratio is usually greater than 2.7 .

The limitations of present study make our results difficult to interpret in clinical use because participants were not drug-naïve patients. Atypical antipsychotics given to patients, such as quatiepine and risperidone, are antagonists of the MAO type $A$ enzymes which are responsible for the antidepressant effects of these monoamine oxidase inhibitors. In future studies, drug-naïve patients will be more

\section{References}

1. Sawa A, Snyder SH. Schizophrenia: diverse approaches to a complex disease. Science 2002; 296: 692-5.

2. Portin P, Alanen YO. A critical review of genetic studies of schizophrenia. II. Molecular genetic studies. Acta Psychiatr Scand 1997; 95: 73-80.

3. Sokoloff P, Le Foll B. The dopamine D3 receptor, a quarter century later. Eur J Neurosci 2017; 45: 2-19.

4. Weinstein JJ, Chohan MO, Slifstein M, Kegeles LS, Moore $\mathrm{H}$, Abi-Dargham A. Pathway-specific dopamine abnormalities in schizophrenia. Biol Psychiat 2017; 81: 31-42.

5. Stone JM, Morrison PD, Pilowsky LS. Glutamate and dopamine dysregulation in schizophrenia-a synthesis and selective review. J Psychopharmacol 2007; 21: 440 52. appropriate to determine whether renalase has potential clinical use in schizophrenia. However, to our knowledge, this is the first report in the literature describing an association between renalase and schizophrenia.

Taken together, the relationship between low levels of renalase and high levels of DA might have an important role in the development of schizophrenia. As suggested previously, improper renalase levels caused by changes in the brain in schizophrenia patients may contribute over time to failure in DA metabolism. This result can cause high levels of DA and low levels of renalase in the brain, thus resulting in the development of schizophrenia (19). After intrabrain renalase and DA dynamics are clearly understood, renalase may emerge as a new target for therapeutic development for treating schizophrenia. We also think that renalase and DA measurements may contribute to the clinical diagnosis of schizophrenia.

\section{Highlights}

1) Renalase levels are lower in schizophrenia patients than in controls

2) Dopamine levels are higher in schizophrenia patients than in controls

1) Low levels of renalase cannot metabolize dopamine; thus, schizophrenia might develop

2) Renalase treatment might be a new remedy for schizophrenia in the future

3) Low renalase is not linked to Epi levels

\section{Conflict of interest statement}

The authors stated that they have no conflicts of interest regarding the publication of this article.

6. Marić PN, Pejović Nikolić S, Buzadžić I, Jovičić $M$, Andrić S, Mihaljević M, Pavlović Z. „Treatment Resistance» Enigma Resolved by Pharmacogenomics - A Case Study of Clozapine Therapy in Schizophrenia. J Med Biochem 2015; 34: 223-7.

7. Yang AC, Tsai SJ, New Targets for Schizophrenia Treatment beyond the Dopamine Hypothesis. Int J Mol Sci 2017; 18: 1689.

8. Zai G, Robbins TW, Sahakian BJ, Kennedy JL. A review of molecular genetic studies of neurocognitive deficits in schizophrenia. Neurosci Biobehav Rev 2017; 72: 50-67.

9. Brisch R, Saniotis A, Wolf R, Bielau H, Bernstein HG, Steiner J, et al. The role of dopamine in schizophrenia from a neurobiological and evolutionary perspective: old fashioned, but still in vogue. Front Psychiatry 2014; 5: 47. 
10. Barral S, Habeck C, Gazes E, De Jager PL, Bennett DA, Stern Y. A dopamine receptor genetic variant enhances perceptual speed in cognitive healthy subjects. Alzheimers Dement 2017; 3: 254-61.

11. Gonsai NH, Amin VH, Mendpara GC, Speth R, Hale GM. Effects of dopamine receptor antagonist antipsychotic therapy on blood pressure. J Clin Pharm Ther 2018; 43: 1-7.

12. Xu J, Li G, Wang P, Velazquez H, Yao X, Li Y, et al. Renalase is a novel, soluble monoamine oxidase that regulates cardiac function and blood pressure. J Clin Invest 2005; 115: 1275-80.

13. Desir GV, Peixoto AJ, Renalase in hypertension and kidney disease. Nephrol Dial Transplant 2014; 29: 22-8.

14. Hennebry SC, Eikelis N, Socratous F, Desir G, Lambert G, Schlaich M. Renalase, a novel soluble FAD-dependent protein, is synthesized in the brain and peripheral nerves. Mol Psychiatry 2010; 15: 234-6.

15. Quelhas-Santos J, Sampaio-Maia B, Remião F, Serrão $P$, Soares-Silva I, Desir GV, et al. Assessment of Renalase Activity on Catecholamines Degradation. The Open Hypertension Journal 2015; 7: 14-8.

16. Di Giovanni G, Svob Strac D, Sole M, Unzeta M, Tipton KF, Mück- eler D, et al. Monoaminergic and histaminergic strategies and treatments in brain diseases. Front Neurosci 2016; 10: 541.

17. Naoi M, Maruyama W, Shamoto-Nagai M. Type A and B monoamine oxidases distinctly modulate signal transduction pathway and gene expression to regulate brain function and survival of neurons. J Neural Transm 2017; Article in press.

18. Quelhas-Santos J, Serrão MP, Soares-Silva I, FernandesCerqueira C, Simões-Silva L, Pinho MJ, et al. Renalase regulates peripheral and central dopaminergic activities. Am J Physiol Renal Physiol 2015; 308: 84-91.

19. Aydin MA, Aydin S. Can Renalase Enzyme Control the Fate of Parkinson's and Schizophrenia? J Biochem Physiol 2018; 1: 1.

20. Aydin S. A short history, principles, and types of ELISA, and our laboratory experience with peptide/protein analyses using ELISA. Peptides 2015; 72: 4-15.

21. Grace AA. Dopamine system dysregulation and the pathophysiology of schizophrenia: insights from the methylazoxymethanol acetate model. Biol Psychiatry 2017; 81: 5-8.

22. Howes OD, McCutcheon R, Owen MJ, Murray RM. The role of genes, stress, and dopamine in the development of schizophrenia. Biol Psychiatry 2017; 81: 9-20.

23. Tomasella E, Bechelli L, Ogando MB, Mininni C, Di Guilmi MN, De Fino F, et al. Deletion of dopamine D2 receptors from parvalbumin interneurons in mouse causes schizophrenia-like phenotypes. Proc Natl Acad Sci 2018; 115: 3476-81.

24. Elenkov IJ, Wilder RL, Chrousos GP, Vizi ES. The sympathetic nerve - an integrative interface between two supersystems: the brain and the immune system. Pharmacol Rev 2000; 52: 595-638.

25. Bellono NW, Bayrer JR, Leitch DB, Castro J, Zhang C, O'Donnell TA, et al. Enterochromaffin cells are gut chemosensors that couple to sensory neural pathways. Cell 2017; 170: 185-98.

26. Aydin S, Aydin S. Can Strict Control of Renalase Present a New Treatment Alternative in Regulating Blood Pressure. J Cardiovasc Med Cardiol 2017; 4: 008-9.

27. Lemiesz M, Tenderenda-Banasiuk E, Sosnowska D, Taranta-Janusz K, Wasilewska A. Serum Renalase Levels in Adolescents with Primary Hypertension. Pediatr Cardiol 2018; 30: 1-7.

28. Kesby JP, Eyles DW, McGrath JJ, Scott JG. Dopamine, psychosis and schizophrenia: the widening gap between basic and clinical neuroscience. Transl Psychiatry 2018; 8: 30 .

29. Yi-Sha H, Jian-Bo L, Sheng-Fa L, Ting W, Ying-Nan L, Qing-Xi, Z, et al. Relationship between Renalase Expression and Kidney Disease: an Observational Study in 72 Patients Undergoing Renal Biopsy. Current Medical Science 2018; 38: 268-76.

30. Grassi G, Mark A, Esler M. The sympathetic nervous system alterations in human hypertension. Circ Res 2015; 116: 976-90.

31. Wang F, Li J, Xing T, Xie Y, Wang N. Serum renalase is related to catecholamine levels and renal function. Clin Exp Nephrol 2015; 19: 92-8.

32. Yılmaz ZV, Akka E, Yıldırım T, Yılmaz R, Erdem Y. A novel marker in pregnant with preeclampsia: renalase. J Matern Fetal Neonatal Med 2017; 30: 808-13. 